\title{
PENGARUH RICH MEDIA ADVERTISING TERHADAP KEPUTUSAN PEMBELIAN PAKET BULAN MADU BALI KEROBOKAN-SEMINYAK-PETITENGET DI BULANMADU.COM
}

\author{
Rizki Nurul Nugraha \\ Email: miawkie@yahoo.com \\ Program Studi Pariwisata Fakultas Ekonomi \\ Universitas Nasional
}

\begin{abstract}
ABSTRAK
Penelitian ini bertujuan untuk menganalisis pengaruh rich media advertising terhadap keputusan pembelian paket bulan madu Bali Kerobokan - Seminyak - Petitenget di bulanmadu.com. Populasi dalam penelitian ini adalah pengguna jasa paket bulan madu Bali Kerobokan - Seminyak - Petitenget di bulanmadu.com pada rentang waktu 3 tahun terakhir. Penelitian ini melibatkan 100 pengguna jasa yang diambil secara random. Metode analisis yang digunakan adalah metode analisis jalur (path). Hasil penelitian menunjukkan bahwa streaming audio, streaming video, applets that allow user interaction dan special effect secara parsial berpengaruh positif dan signifikan terhadap keputusan pembelian paket bulan madu Bali Kerobokan - Seminyak - Petitenget di bulanmadu.com. Berdasarkan hasil tersebut, dapat disimpulkan bahwa rich media advertising memiliki pengaruh yang positif dan signifikan terhadap keputusan pembelian paket bulan madu Bali Kerobokan - Seminyak Petitenget di bulanmadu.com.
\end{abstract}

Kata kunci: Rich media advertising, audio streaming, video streaming, applets that allow user interaction, special effect

ABSTRACT
This study aims to analyze the effect of rich media advertising on purchasing decision of Bali Kerobokan - Seminyak - Petitenget honeymoon package in bulanmadu.com. Population in this study is consumers of Bali Kerobokan - Seminyak - Petitenget honeymoon package in bulanmadu.com in the last 3 years. This study involve 100 users of service as a research subject that were taken at random. Analysis method that used was path analysis method. The results of study showed that streaming audio, streaming video, applets that allow user interaction and special effect partially has positive and significant effect on purchasing decision of Bali Kerobokan - Seminyak - Petitenget honeymoon package in bulanmadu.com. According to the results, it can be concluded that rich media advertising has positive and significant effect on purchasing decison of Bali Kerobokan - Seminyak - Petitenget honeymoon package in bulanmadu.com.

Keywords: Rich media advertising, audio streaming, video streaming, applets that allow user interaction, special effect

\section{PENDAHULUAN}

Sektor pariwisata di Indonesia telah mengalami perkembangan yang pesat dan bertransformasi menjadi salah satu kekuatan yang menggerakkan perekonomian nasional. Salah satu andalan Indonesia di sektor pariwisata adalah Bali. Pada tahun 2017, Bali bahkan 
dinobatkan sebagai The World's Best Destination dalam ajang TripAdvisor Travellers' Choice Award 2017 yang diselenggarakan oleh TripAdvisor, yaitu situs penyedia berbagai informasi tentang turisme yang berbasis di Amerika Serikat (CNN Indonesia, 2017).

Paket wisata bulan madu ke Bali merupakan salah satu paket wisata yang tidak pernah sepi dari peminat. Tingginya permintaan paket wisata bulan madu ke Bali menimbulkan bermunculannya perusahaan-perusahaan jasa perjalanan yang menawarkan paket tersebut. Perusahaan-perusahaan jasa perjalanan tersebut saling bersaing untuk menawarkan paket bulan madu yang paling menarik bagi calon pengguna jasanya. Salah satu perusahaan yang menawarkan paket bulan madu adalah Bulanmadu.com.

Bulanmadu.com adalah perusahaan jasa perjalanan di Indonesia yang dirancang khusus untuk menawarkan perjalanan bulan madu dan perjalanan romantis lainnya (Bulanmadu.com, 2017). Dari seluruh paket bulan madu yang ditawarkannya, paket Bali Kerobokan - Seminyak - Petitenget merupakan paket bulan madu yang membukukan total penjualan tertinggi.

Berdasarkan data yang diperoleh dari bagian marketing bulanmadu.com, penjualan paket Bali Kerobokan - Seminyak - Petitenget di bulanmadu.com mengalami fluktuasi selama tahun 2012-2014. Penjualan paket mengalami kenaikan pada tahun 2013, tetapi mengalami penurunan pada tahun 2014. Penurunan tersebut perlu ditanggapi dengan serius untuk mencegah terjadinya penurunan penjualan yang lebih tinggi lagi di masa yang akan datang. Diperlukan suatu variabel tertentu yang dapat dijadikan sebagai alat untuk meningkatkan keputusan pembelian terhadap paket bulan madu Bali Kerobokan - Seminyak - Petitenget di bulanmadu.com. Oleh karena itu, perlu dilakukan penelitian untuk menganalisis variabel yang dapat mempengaruhi keputusan pembelian paket bulan madu tersebut.

Salah satu variabel yang dapat mempengaruhi keputusan pembelian adalah rich media advertising, yaitu jenis advertising yang merupakan pengembangan dari internet advertising. Menurut Goldsmith dan Lafferty (2002) dalam Osewe (2013), internet advertising merupakan kunci penting yang menentukan keputusan pembelian customer. Hal tersebut terjadi karena semakin baik strategi internet advertising yang digunakan oleh suatu perusahaan, maka semakin tinggi tingkat ketertarikan masyarakat untuk menggunakan produk/jasa yang ditawarkan oleh perusahaan tersebut, sehingga semakin tinggi pula tingkat keputusan pembelian yang diambil oleh masyarakat terhadap produk/jasa yang ditawarkan oleh perusahaan yang dimaksud.

Dalam mempromosikan paket bulan madu yang ditawarkannya, bulanmadu.com menggunakan rich media advertising. Menurut Susan, et al. (2006), rich media advertising 
merupakan strategi advertising yang meliputi dimensi streaming audio, streaming video, applets that can allow user interaction dan special effects. Dalam rangka menjalankan rich media advertising, Bulanmadu.com mengembangkan website yang atraktif sebagai media pemasaran online yang mengikuti trend pasar terbaru. Selama hampir 10 tahun, belum ada keluhan ketidakpuasan pengguna jasa terhadap rich media advertising yang dilakukan oleh Bulanmadu.com.

Sebagai bentuk pengembangan dari internet advertising, rich media advertising dapat memiliki pengaruh yang positif dan signifikan terhadap keputusan pembelian. Akan tetapi, meskipun telah menggunakan rich media advertising, penjualan paket bulan madu Bali Kerobokan - Seminyak - Petitenget di bulanmadu.com justru mengalami penurunan pada tahun 2014. Hal tersebut menunjukkan adanya gap antara bukti empiris dan hasil penelitian terdahulu.

Berdasarkan latar belakang di atas, perlu dilakukan penelitian untuk menganalisis pengaruh rich media advertising terhadap keputusan pembelian paket bulan madu Bali Kerobokan - Seminyak - Petitenget di bulanmadu.com.

\section{TINJAUAN PUSTAKA}

\section{Rich Media Advertising}

Menurut Shimp (2000:369), media adalah metode komunikasi umum yang memuat pesan dari suatu advertising televisi, majalah, surat kabar, internet dan sebagainya. Adapun Kotler dan Armstrong (2012) mendefinisikan advertising sebagai setiap bentuk penyajian gagasan, barang atau jasa yang dibayar, yang sifatnya bukan pribadi oleh sponsor yang dapat dikenali media penyajiannya meliputi majalah, surat kabar, radio, TV, tanda dan selebaran. Menurut Lupiyoadi (2014:178), iklan (advertising) merupakan salah satu bentuk dari komunikasi impersonal (impersonal communication) yang digunakan oleh perusahaan dalam mengkomunikasikan produknya, baik barang maupun jasa.

Menurut Osewe (2013), internet advertising adalah suatu bentuk promosi yang menggunakan internet dan worldwide web untuk menyampaikan tujuan pengiriman pesan marketing dengan tujuan menarik customer. Rich media advertising adalah istilah yang digunakan untuk menggambarkan berbagai pengalaman media yang menawarkan pengalaman interaktif yang disempurnakan (Susan, et al., 2006:42). 


\section{Dimensi Rich Media Advertising}

Menurut Susan, et al. (2006:42) rich media advertising mencakup hal-hal sebagai berikut.

1. Streaming audio, yaitu audio yang selalu diterima dan disajikan kepada pengguna akhir langsung ketika dikirimkan oleh penyedia.

2. Streaming video, yaitu aliran data dari suatu server.

3. Applets that allow user interaction, yaitu suatu ruang terjadinya interaksi antara manusia dan mesin.

4. Special effects, yaitu efek khusus yang dibuat dan/atau dimanipulasi di luar konteks pengambilan live action.

\section{Keputusan Pembelian}

Menurut Schiffman dan Kanuk (2008), keputusan pembelian merupakan suatu keputusan sebagai pemilihan suatu tindakan dari dua atau lebih pilihan alternatif. Menurut Pitana dan Gayatri (2005:71) dalam Kristiutami (2015:81), keputusan untuk melakukan perjalanan pada dasarnya adalah keputusan pembelian, yaitu mengeluarkan uang untuk mendapatkan kepuasan akan tetapi pembelian dalam konteks pariwisata mempunyai beberapa keleluasaan.

Menurut Kotler dan Armstrong (2012:171), konsumen memiliki enam dimensi keputusan pembelian, yaitu pemilihan produk/jasa, pemilihan pemasok, jumlah pesanan, persyaratan dan waktu pembelian, persyaratan pelayanan, dan pembayaran.

Menurut Tjiptono dan Chandra (2012:127), terdapat empat macam situasi yang berpengaruh terhadap keputusan pembelian konsumen, yaitu sebagai berikut.

1. Situasi komunikasi, yaitu situasi saat konsumen menerima informasi mengenai produk dan jasa.

2. Situasi pembelian, yaitu situasi yang mempengaruhi pemilihan produk.

3. Situasi pemakaian, yaitu kondisi konsumsi produk atau jasa yang dibeli.

4. Situasi penghentian pemakaian, yaitu situasi sewaktu produk dan atau kemasan produk dibuang sebelum atau sesudah digunakan.

\section{Pengaruh Rich Media Advertising terhadap Keputusan Pembelian}

Salah satu variabel yang dapat mempengaruhi keputusan pembelian adalah rich media advertising, yaitu jenis advertising yang merupakan pengembangan dari internet advertising. Menurut Goldsmith dan Lafferty (2002) dalam Osewe (2013), internet advertising 
merupakan kunci penting yang menentukan keputusan pembelian customer. Hal tersebut terjadi karena semakin baik strategi internet advertising yang digunakan oleh suatu perusahaan, maka semakin tinggi tingkat ketertarikan masyarakat untuk menggunakan produk/jasa yang ditawarkan oleh perusahaan tersebut, sehingga semakin tinggi pula tingkat keputusan pembelian yang diambil oleh masyarakat terhadap produk/jasa yang ditawarkan oleh perusahaan yang dimaksud.

Rich media menarik bagi pengiklan karena dapat menyampaikan pesan secara efektif dengan menggunakan audio, video, dan animasi. Efektivitas tersebut akan membantu meningkatkan brand recognition. Bagi konsumen, rich media advertising lebih menarik karena lebih menghibur, lebih informatif, lebih relevan, dan lebih tepat waktu (Susan, et al., 2006:43). Tingginya daya tarik rich media advertising bagi konsumen akan meningkatkan daya tarik dari barang/jasa yang ditawarkan oleh advertising tersebut, sehingga diharapkan dapat meningkatkan keputusan pembelian atas barang atau layanan jasa yang diiklankan tersebut.

$\mathrm{H}_{1}$ : Rich media advertising berpengaruh positif dan signifikan terhadap keputusan pembelian paket bulan madu Bali Kerobokan - Seminyak - Petitenget di bulanmadu.com.

$\mathrm{H}_{1 \mathrm{~A}}$ : Streaming audio berpengaruh positif dan signifikan terhadap keputusan pembelian paket bulan madu Bali Kerobokan - Seminyak - Petitenget di bulanmadu.com.

$\mathrm{H}_{1 \mathrm{~B}}$ : Streaming video berpengaruh positif dan signifikan terhadap keputusan pembelian paket bulan madu Bali Kerobokan - Seminyak - Petitenget di bulanmadu.com.I

$\mathrm{H}_{1 \mathrm{C}}$ : Applets that allow user interaction berpengaruh positif dan signifikan terhadap keputusan pembelian paket bulan madu Bali Kerobokan - Seminyak - Petitenget di bulanmadu.com.

$\mathrm{H}_{1 \mathrm{D}}$ : Special Effects berpengaruh positif dan signifikan terhadap keputusan pembelian paket bulan madu Bali Kerobokan - Seminyak - Petitenget di bulanmadu.com. 


\section{Kerangka Analisis}

Kerangka analisis dari penelitian ini dapat dilihat dari gambar sebagai berikut.

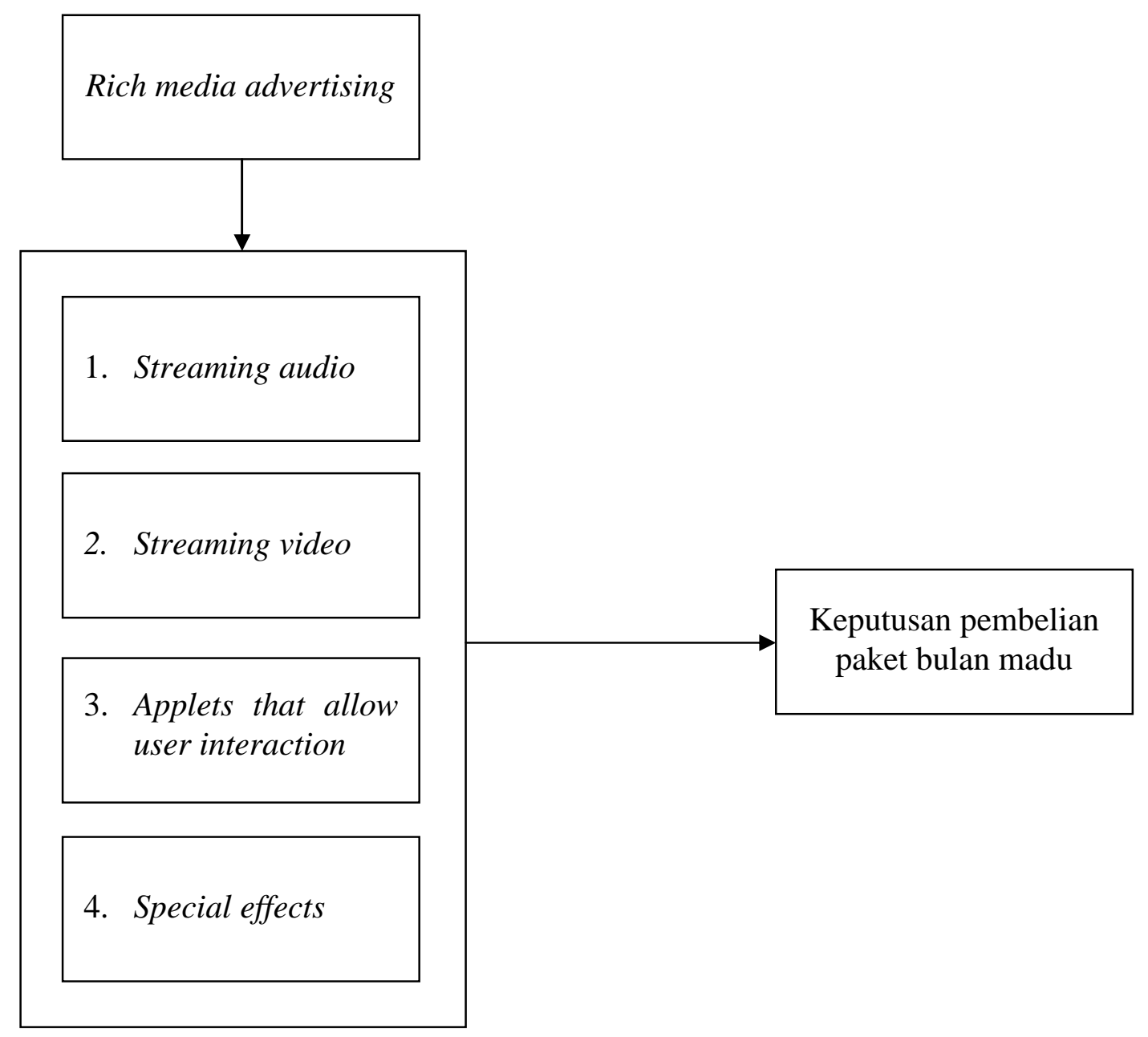

Gambar 1. Kerangka Analisis

\section{METODE PENELITIAN}

\section{Sumber dan Jenis Data}

Data yang digunakan dalam penelitian ini adalah data primer yang diperoleh dari hasil penyebaran kuesioner kepada responden yang bersangkutan.

\section{Populasi dan Sampel}

Populasi dalam penelitian ini adalah pengguna jasa paket bulan madu Bali Kerobokan - Seminyak - Petitenget di bulanmadu.com pada rentang waktu 3 tahun terakhir. Dengan menggunakan rumus Slovin, sampel yang digunakan dalam penelitian ini terdiri dari 100 responden. 


\section{Operasionalisasi Variabel}

Berikut ini merupakan operasionalisasi dari variabel-variabel yang digunakan dalam penelitian ini.

Tabel 2. Tabel Operasionalisasi Variabel

\begin{tabular}{|c|c|c|}
\hline Variabel & Subvariabel & Indikator \\
\hline \multirow{4}{*}{$\begin{array}{l}\text { Rich media } \\
\text { advertising }\end{array}$} & Streaming Audio & $\begin{array}{l}\text { - Kejelasan suara dalam memberikan informasi } \\
\text { mengenai paket } \\
\text { - Kemudahan konsumen dalam mendengar } \\
\text { informasi melalui streaming audio } \\
\text { (Sumber: Andeligh dalam Beningthon, 2010:6) }\end{array}$ \\
\hline & Streaming video & $\begin{array}{l}\text { - Kemenarikan video dalam memberikan informasi } \\
\text { - Kejelasan video dalam memberikan informasi } \\
\text { mengenai paket yang di tawarkan } \\
\text { (Sumber: Andeligh dalam Beningthon, 2010:9) }\end{array}$ \\
\hline & $\begin{array}{c}\text { Applets that allow } \\
\text { user interaction }\end{array}$ & $\begin{array}{l}\text { - Konsistensi dalam memberikan informasi dari } \\
\text { media sosial } \\
\text { - Kemudahan interaksi konsumen melalui online } \\
\text { social media } \\
\text { (Sumber: Curren dalam Hadinata, 2011:34) }\end{array}$ \\
\hline & Special effects & $\begin{array}{l}\text { - Kemenarikan graphic card dalam memberikan } \\
\text { special effect pada form penawaran paket } \\
\text { (Sumber: Andeligh dalam Beningthon, 2010:14) }\end{array}$ \\
\hline \multirow{6}{*}{\multicolumn{2}{|c|}{ Keputusan Pembelian }} & Pilihan produk Barang dan jasa \\
\hline & & Frekuensi pembelian \\
\hline & & Pemilihan brand (merek) \\
\hline & & Pilihan distribusi \\
\hline & & Waktu penggunaan \\
\hline & & $\begin{array}{l}\text { Metode pembayaran } \\
\text { (Sumber: Kotler dan Keller, 2012) }\end{array}$ \\
\hline
\end{tabular}

\section{Analisis Jalur (Path Analysis)}

Metode analisis yang digunakan dalam penelitian ini adalah analisis jalur (path analysis). Menurut Bohrnstedt dalam Kusnaedi (2005), analisis jalur adalah suatu teknik untuk mengukur pengaruh dari beberapa independen variabel terhadap suatu variabel dependen dari sekelompok korelasi yang diamati, berdasarkan suatu hipotesis hubungan kausal antarvariabel.

Berikut ini merupakan diagram analisis jalur yang digunakan dalam penelitian ini. 


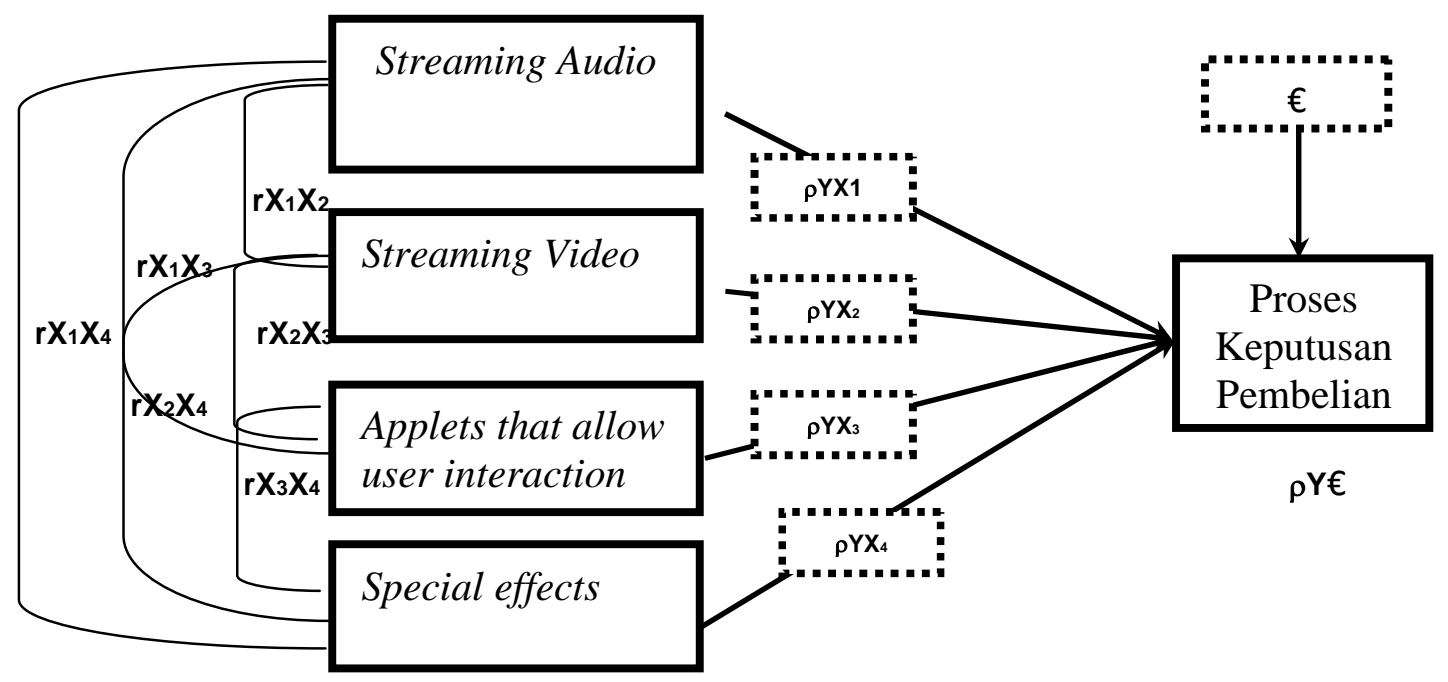

\section{Gambar 1. Diagram Analisis Jalur}

\section{HASIL PENELITIAN DAN PEMBAHASAN}

\section{Hasil Pengujian Validitas}

Hasil pengujian validitas menunjukkan bahwa setiap butir pertanyaan dari variabel penelitian ini bersifat valid karena memiliki $r_{\text {hitung }}$ yang lebih besar daripada $r_{\text {tabel. }}$

\section{Hasil Uji Simultan (Uji F)}

Berdasarkan hasil uji F, diperoleh $\mathrm{F}_{\text {hitung }}$ sebesar 5,008 dengan nilai signifikan sebesar $0,001<0,05$, sehingga dapat disimpulkan bahwa streaming audio, streaming video, applets that allow user interaction dan special effect secara bersama-sama berpengaruh positif dan signifikan terhadap keputusan pembelian paket bulan madu di bulanmadu.com.

\section{Hasil Pengujian Hipotesis (Uji t)}

Hasil pengujian hipotesis penelitian disajikan dalam tabel sebagai berikut.

Tabel 3. Hasil Koefisien Jalur

\begin{tabular}{|c|c|c|c|c|c|}
\hline \multirow{2}{*}{ Model } & \multicolumn{2}{|c|}{$\begin{array}{c}\text { Unstandardized } \\
\text { Coefficients }\end{array}$} & \multirow{2}{*}{$\begin{array}{c}\begin{array}{c}\text { Standardized } \\
\text { Coefficients }\end{array} \\
\text { Beta }\end{array}$} & \multirow{2}{*}{$\mathbf{T}$} & \multirow{2}{*}{ Sig. } \\
\hline & B & $\begin{array}{c}\text { Std. } \\
\text { Error }\end{array}$ & & & \\
\hline (Constant) & 5,720 & 2,680 & & 2,134 & 0,035 \\
\hline $\mathrm{X}_{1}$ & 0,789 & 0,051 & 0,586 & 15,390 & 0,000 \\
\hline$X_{2}$ & 0,904 & 0,117 & 0,306 & 7,748 & 0,000 \\
\hline$X_{3}$ & 0,999 & 0,127 & 0,296 & 7,873 & 0,000 \\
\hline $\mathrm{X}_{4}$ & 0,897 & 0,137 & 0,244 & 6,525 & 0,000 \\
\hline
\end{tabular}

(Sumber: Data diolah, 2015) 
Berdasarkan tabel di atas, setiap variabel bebas memiliki nilai $\mathrm{t}_{\text {hitung }}$ yang positif dengan nilai signifikan yang lebih kecil daripada $\alpha$ sebesar 0,05 . Hal tersebut menunjukkan bahwa streaming audio, streaming video, applets that allow user interaction dan special effects secara parsial berpengaruh positif dan signifikan terhadap keputusan pembelian paket bulan madu Bali Kerobokan - Seminyak - Petitenget di bulanmadu.com.

Berikut ini merupakan tabel pengaruh dari setiap variabel penelitian.

Tabel 4. Pengaruh Variabel Penelitian

\begin{tabular}{|c|c|c|c|c|c|}
\hline & $\mathbf{Y}$ & $\mathbf{X}_{\mathbf{1}}$ & $\mathbf{X}_{\mathbf{2}}$ & $\mathbf{X}_{\mathbf{3}}$ & $\mathbf{X}_{\mathbf{4}}$ \\
\hline $\mathbf{Y}$ & 1.000 & 0,353 & 0,036 & 0,003 & 0,408 \\
\hline $\mathbf{X}_{\mathbf{1}}$ & 0,353 & 1,000 & 0,711 & 0,765 & 0,628 \\
\hline $\mathbf{X}_{\mathbf{2}}$ & 0,036 & 0,711 & 1,000 & 0,731 & 0,679 \\
\hline $\mathbf{X}_{\mathbf{3}}$ & 0,003 & 0,765 & 0,731 & 1,000 & 0,677 \\
\hline $\mathbf{X}_{\mathbf{4}}$ & 0,408 & 0,628 & 0,679 & 0,677 & 1,000 \\
\hline
\end{tabular}

(Sumber: Data diolah, 2015)

Berikut ini merupakan tabel pengaruh langsung dan tidak langsung dari setiap variabel bebas terhadap variabel terikat.

Tabel 5. Pengaruh Langsung dan Tidak Langsung Variabel Penelitian

\begin{tabular}{|l|l|l|l|l|}
\hline & \multicolumn{1}{|c|}{$\mathbf{X}_{\mathbf{1}}$} & \multicolumn{1}{|c|}{$\mathbf{X}_{\mathbf{2}}$} & \multicolumn{1}{|c|}{$\mathbf{X}_{\mathbf{3}}$} & \multicolumn{1}{|c|}{$\mathbf{X}_{\mathbf{4}}$} \\
\hline Pengaruh langsung & 0,1246 & 0,0013 & 0,000009 & 0,16646 \\
\hline Melalui hubungan korelatif dengan $\mathrm{X}_{1}$ & & 0,0090 & 0,0008 & 0,0904 \\
\hline Melalui hubungan korelatif dengan $\mathrm{X}_{2}$ & 0,0090 & & 0,0001 & 0,0097 \\
\hline Melalui hubungan korelatif dengan $\mathrm{X}_{3}$ & 0,0008 & 0,0001 & & 0,00082 \\
\hline Melalui hubungan korelatif dengan $\mathrm{X}_{4}$ & 0,0904 & 0,00997 & 0,00082 & \\
\hline Total pengaruh & 0,2248 & 0,02024 & 0,0017 & 0,26765 \\
\hline $\begin{array}{l}\text { Pengaruh gabungan } \mathrm{X}_{1}, \mathrm{X}_{2}, \mathrm{X}_{3}, \mathrm{X}_{4} \\
\text { terhadap Y }\end{array}$ & \multicolumn{4}{|c|}{0,5145} \\
\hline
\end{tabular}

(Sumber: Data diolah, 2015)

Berdasarkan tabel di atas, dapat diketahui bahwa besarnya pengaruh rich media advertising terhadap keputusan pembelian paket bulan madu Bali Kerobokan - Seminyak Petitenget di bulanmadu.com adalah 51,45\% .

\section{Pembahasan}

\section{Pengaruh Streaming Audio terhadap Keputusan Pembelian}

Hasil penelitian ini menunjukkan bahwa streaming audio berpengaruh positif dan signifikan terhadap keputusan pembelian paket bulan madu Bali Kerobokan - Seminyak Petitenget di bulanmadu.com. Penggunaan streaming audio sebagai salah satu media dalam rich advertising pada paket bulan madu Bali Kerobokan - Seminyak - Petitenget di bulanmadu.com cenderung lebih menarik jika dibandingkan dengan penggunaan iklan yang 
hanya menampilkan tulisan semata. Streaming audio juga dapat secara lebih efektif membantu pengguna jasa untuk mengetahui paket bulan madu yang ditawarkan tanpa harus membaca. Tingginya daya tarik dan informasi praktis yang ditawarkan oleh media streaming audi tersebut terbukti dapat meningkatkan keputusan pembelian paket bulan madu Bali Kerobokan - Seminyak - Petitenget di bulanmadu.com.

Dalam penelitian ini, 61\% sampel yang digunakan merupakan pengguna jasa yang berada di usia 25-40 tahun. Orang-orang pada usia tersebut cenderung membutuhkan kacamata sebagai alat bantu untuk membaca suatu informasi. Oleh karena itu, streaming audio akan membantu memudahkan pengguna jasa untuk memperoleh informasi yang dibutuhkannya terkait paket bulan madu tanpa perlu mencari alat bantu baca untuk membaca informasi yang tertuang di dalam website.

Fluktuasi penjualan yang dialami oleh bulanmadu.com dapat disebabkan oleh kurang detailnya informasi paket bulan madu yang disediakan dalam streaming audio. Besarnya kuota yang diperlukan untuk merekam audio advertising dari setiap paket bulan madu menyebabkan informasi yang disediakan di dalam audio tersebut tidak dapat dijelaskan secara detail.

\section{Pengaruh Streaming Video terhadap Keputusan Pembelian}

Hasil penelitian ini menunjukkan bahwa streaming video berpengaruh positif dan signifikan terhadap keputusan pembelian paket bulan madu Bali Kerobokan - Seminyak Petitenget di bulanmadu.com. Streaming video dapat menyediakan informasi yang jelas mengenai paket bulan madu yang ditawarkan, sehingga dapat meningkatkan kepercayaan dan menggugah rasa ingin tahu orang yang menonton video tersebut. Pada akhirnya, hal tersebut akan meningkatkan keputusan pembelian terhadap paket bulan madu Bali Kerobokan Seminyak - Petitenget di bulanmadu.com.

Fluktuasi penjualan yang dialami oleh bulanmadu.com dapat disebabkan oleh adanya keterbatasan penyimpanan data visual yang mengakibatkan perusahaan hanya menyertakan sebagian gambar yang dianggap dapat menarik minat calon pengguna jasa. Hal tersebut terjadi karena ukuran video yang terlalu besar dapat menyulitkan sebagian besar para calon pengguna jasa untuk mengakses website yang menyediakan video tersebut melalui smartphone-nya. Keterbatasan penyimpanan data visual tersebut akan mengurangi visualisasi informasi yang diberikan kepada calon pengguna jasa, sehingga dapat mengurangi optimalisasi advertising yang dilakukan. Pada akhirnya, hal tersebut akan mengurangi potensi realisasi pembelian yang dilakukan oleh pengguna jasa. 


\section{Pengaruh Applets that Allow User Interaction terhadap Keputusan Pembelian}

Hasil penelitian ini menunjukkan bahwa applets that allow user interaction berpengaruh positif dan signifikan terhadap keputusan pembelian paket bulan madu Bali Kerobokan - Seminyak - Petitenget di bulanmadu.com. Applets that allow user interaction dapat meningkatkan informasi yang diperoleh calon pengguna jasa terkait paket bulan madu yang ditawarkan oleh perusahaan, khususnya informasi yang berkaitan dengan keunggulan paket yang ditawarkan. Hal tersebut akan meningkatkan ketertarikan calon pengguna jasa untuk membeli paket bulan madu yang ditawarkan tersebut, sehingga akan meningkatkan keputusan pembelian terhadap paket bulan madu yang dimaksud.

Fluktuasi penjualan yang dialami oleh bulanmadu.com dapat disebabkan oleh media interaksi langsung dalam applets that allow user interaction yang seringkali berada dalam keadaan offline. Hal tersebut dapat mengurangi pemenuhan informasi yang dibutuhkan oleh calon pengguna jasa terkait paket bulan madu yang ditawarkan oleh perusahaan, sehingga dapat menimbulkan keraguan di dalam diri calon pengguna jasa tersebut untuk membuat suatu keputusan pembelian.

\section{Pengaruh Special Effects terhadap Keputusan Pembelian}

Hasil penelitian ini menunjukkan bahwa special effects berpengaruh positif dan signifikan terhadap keputusan pembelian paket bulan madu Bali Kerobokan - Seminyak Petitenget di bulanmadu.com. Special effects dapat meningkatkan daya tarik dari website dan advertising yang disajikan di dalam website itu sendiri. Hal tersebut akan meningkatkan jumlah pengunjung yang membaca, melihat dan mendengarkan konten rich media advertising di dalam website tersebut, sehingga akan meningkatkan keputusan pembelian terhadap paket bulan madu yang ditawarkan di dalam website yang dimaksud. Berdasarkan hasil tersebut, fluktuasi penjualan yang dialami oleh bulanmadu.com dapat disebabkan oleh belum optimalnya penggunaan special effects oleh perusahaan.

\section{KESIMPULAN DAN SARAN}

\section{Kesimpulan}

Berdasarkan hasil penelitian ini, dapat disimpulkan bahwa rich media advertising yang diproksikan dengan streaming audio, streaming video, applets that can allow user interaction dan special effects memiliki pengaruh yang positif dan signifikan terhadap keputusan pembelian paket bulan madu Bali Kerobokan-Seminyak-Petitenget di bulanmadu.com. 


\section{Saran}

Berdasarkan hasil penelitian ini, saran yang dapat dipertimbangkan untuk dilakukan oleh perusahaan antara lain sebagai berikut.

1. Perusahaan hendaknya meningkatkan atau memperpadat detail penjelasan yang disediakan di dalam streaming audio dari rich advertising yang digunakannya.

2. Perusahaan hendaknya memperhatikan gambar-gambar yang disajikan di dalam streaming video dari rich advertising yang digunakannya. Gambar-gambar yang digunakan tersebut hendaknya merupakan gambar-gambar yang benar-benar merepresentasikan visualisasi keunggulan dari paket bulan madu yang ditawarkan.

3. Perusahaan hendaknya mengatur dan menginformasikan secara jelas mengenai rentang waktu layanan informasi interaktif melalui media yang disediakan di dalam applets that allow user interaction. Selain itu, perusahaan juga perlu selalu aktif (online) pada rentang waktu yang dimaksud.

4. Perusahaan hendaknya meningkatkan optimalisasi special effects dari rich advertising yang digunakannya.

\section{DAFTAR PUSTAKA}

Bulan Madu. 2017. http://www.bulanmadu.com. 25 April 2017 (10:29).

CNN Indonesia. 2017. Bali Terima Penghargaan Destinasi Wisata Terbaik di Dunia. https://www.cnnindonesia.com/gaya-hidup/20170421134200-307-209237/baliterima-penghargaan-destinasi-wisata-terbaik-di-dunia. 25 April 2017 (09:39).

Goldsmith, R.E. dan B.A. Lafferty. 2002. Consumer Response to Website and Their Influence on Advertising Effectiveness. Journal of Internet Research, Electronic Networking Applications and Policy. 12: 318-328.

Kotler, P. dan G. Armstrong. 2012. The Principles of Marketing. Pearson Prentice Hall. New Jersey.

. dan K.L. Keller. 2012. Marketing Management. 14th Edition. Global Edition. Pearson Prentice Hall. New Jersey.

Kristiutami, Y.P. 2015. Pengaruh Bauran Pemaran terhadap Keputusan Berkunjung Wisatawan di Museum Geologi Bandung. Jurnal Pariwisata. 2(2).

Kusnendi. 2005. Analisis Jalur: Konsep dan Aplikasi dengan Program SPSS dan LISREL 8. JPE FPIPS UPI. Bandung.

Lupiyoadi, R. 2014. Manajemen Pemasaran Jasa Berbasis Kompetensi. Edisi 3. Salemba Empat. Jakarta. 
Osewe, G.O. 2013. The Effectiveness of Internet Advertising on Consumer Behaviour: The Case of University of Nairobi Students. Research Project. School of Business of Univeristy of Nairobi. Nairobi.

Pitana, I.G. dan P.G. Gayatri. 2005. Sosiologi Pariwisata. Andi. Yogyakarta.

Schiffman, L. dan L.S. Kanuk. 2008. Perilaku Konsumen. Edisi Ketujuh. Indeks. Jakarta.

Shimp, T.A. 2000. Advertising, Promotion and Supplemental Aspects of Integrated Marketing Communications. The Dryden Press. London.

Susan, S., A. MacLellan dan E. Dorey. 2006. $3 G$ Marketing on the Internet: Third Generation Internet Marketing Strategies for Online Success. 7th Edition. Maximumm Press. Florida.

Tjiptono, F. dan G. Chandra. 2012. Pemasaran Strategi. Andi. Yogyakarta. 